\title{
Genetic Variability and Heritability among Sugarcane Genotypes at Early Stage of the Advanced Selection for some Agronomic Traits in Ferké, Northern Ivory Coast
}

\author{
YM Béhou ${ }^{1,2} \&$ CB Péné ${ }^{2}$ \\ ${ }^{1}$ Agronomic Sciences and Agricultural Engineering, EDP/INPHB, Yamoussoukro, Ivory Coast \\ ${ }^{2}$ Research and Development Department, SUCAF-CI/SOMDIAA, Ivory Coast \\ Correspondence: Crépin B. PÉNÉ, SUCAF-CI/SOMDIAA Group, Research \& Development Department, 22 rue \\ des Carrossiers, Treichville Zone 3, P.O. Box 1967 Abidjan 01, Ivory Coast. Tel: 225-4783-1916. Email: \\ bpene@sucafci.somdiaa.com/cbpene20@yahoo.com
}

Received: March 15, 2020 Accepted: April 12, 2020 Online Published: April 16, 2020

\begin{abstract}
Selection in sugarcane from true seed was recently implemented in Ivory Coast with the aim to increase the genetic variability of crop material used and, therefore, improve significantly sugar yields with a positive impact on the competitiveness of the Ivorian sugar industry. The objective of study was to determine the best performing cane genotypes among 29 clones tested under sprinkler irrigation, in comparison with a check variety (R579). It was carried out on R3-002 commercial sugarcane plantation of Ferké 2 sugar estate, in northern Ivory Coast. The experimental design used was a randomized complete block with 30 cane genotypes in three replications. Each plot comprised two dual rows of five meters with 0.5 and $1.90 \mathrm{~m}$ of inter-row spacing, i.e. $19 \mathrm{~m}^{2}$ per plot and about $600 \mathrm{~m}^{2}$ for the whole experiment. Based on sugar yields, four promising genotypes namely RCI12/15, RCI12/19, RCI13/121 and RCI13/136 were equivalent to the check variety which performed $15.6 \mathrm{t} / \mathrm{ha}$. They are due to undergo the advanced selection stage during the 2020-21 cropping season for three more years for determining the first new sugarcane varieties of RCI origin to be tested commercially in Ferké sugar estates. Their yield performances ranged from 12.8 to $13.8 \mathrm{t}$ sugar/ha, i.e. from 134.0 to $144.8 \mathrm{t}$ cane/ha compared to $161.3 \mathrm{t} / \mathrm{ha}$ for the control variety. Although a relatively high level of stem-borer infestation rate recorded, with $15.6 \%$ on average (almost three times the tolerable threshold value of 5\%), reasonable values of sucrose percent obtained with the promising genotypes, ranged from 12.7 to $13.9 \%$ over both crop cycles, compared with $13.6 \%$ for the check. Higher heritability values ranging from 61 to $80.5 \%$ were observed in traits like sugar yield, sucrose content $(62.6 \%)$, recoverable sucrose $(60.6 \%)$, fiber content $(72 \%)$, stem-borer infestation rate $(80.5 \%)$, number of internodes/stalk (67.7\%), and flowering rate (79.6\%). In contrast, lower and moderate values of heritability were observed for Pol juice (59.8\%), juice purity (50.5\%), cane yield (53\%), millable stalk number/ha (29.5\%), single stalk weight (36.7\%), single stalk height (45\%), and single stalk diameter (38.7\%).
\end{abstract}

Keywords: phenotypic correlation, genotypic correlation, coefficient of variation, genetic advance, yield trait, juice quality

\section{Introduction}

Sugarcane is a C4 plant grown in tropical and subtropical regions of the world as an important cash crop which contributes to approximatively $80 \%$ of the world sugar production, greatly exceeding sugar beet as a another source of sugar (Dahlquist, 2013). In addition to being a source of sugar, sugarcane is an important bioenergy crop, with an energy ratio of ethanol production five times higher than that of maize (Goldemberg, 2008; Waclawovsky et al, 2010). It is considered by the US Environmental Protection Agency as a feedstock for production of advanced biofuel due to its superior contribution to reduce the life cycle greenhouse gas production in the fight against global warming and climate change (Altpeter and Karan, 2018). In 2003, the FAO estimated that sugarcane had a worldwide gross production value of $\$ 81.5$ billion (FAO, 2013). It was grown on about 27.1 million ha with a world harvest of 1.9 billion metric tons, higher than maize (1.0 billion $t)$, rice (741.0 million $t)$ and wheat (729 million t) (FAO, 2014). Sugarcane is ranked third in quantity of plant calories in the human diet (Moore and Botha, 2013). As a result of its very high biomass production, well-established farming, harvesting and processing technologies, sugarcane is a leading candidate for bioenergy production and a feedstock for bio-refineries. However, productivity improvements in sugarcane have been negligible in the past three decades, and production 
statistics are reflecting decreased yields globally (FAO, 2014). In all cases, increased sugarcane production is linked to expansion of land surface rather than to increases in yield (Jackson, 2005).

Breeding superior commercial cultivars is crucial for maintaining sugarcane production, which will benefit from research in sugarcane genome sequencing and genetic mapping. These research areas focused on understanding sugarcane's genome structure, organization and inheritance patterns. They also help in understanding genetic variations within sugarcane populations or germplasms that control important agronomic traits (Yang et al, 2018).

Usually, the ultimate objective of sugarcane breeding programs is to release varieties which improve the profitability of the sugar industry being targeted. That is why breeders need to determine the optimal weightings that should be applied to each trait being selected for. A first step towards this involves identifying all traits influencing industry stakeholders and determining the relative economic value of variation in each trait, preferably in quantitative terms (Wei et al, 2006). As industries change, the economic value of traits may change. In recent decades, weightings of some traits have changed in response to developments such as the introduction of mechanical harvesting, increased use of sugarcane for energy production and change in agronomic practices. In all sugarcane breeding programs worldwide, the key targeted traits are resistance to important local diseases and pests, commercially extractable sucrose content, cane yield, acceptable fiber content and ratooning performance. In some programs, other traits affecting costs of harvesting or crop management are of importance.

Sugarcane varieties tend to run out or decline after some years of cultivation in a specific area (Khan et al, 2009). To obtain high yield on a sustainable basis, it has been essential to substitute varieties regularly grown with new clones. Sugarcane varieties are clonally propagated and therefore are not expected to undergo genetic changes as it may occur in a seed propagated crop except for the variety decline over several ratoons due to disease incidence and other environmental constraints with therefore a need for replacement (Ali et al, 2017).

Genetic improvement in cane and sugar yields may be achieved by targeting traits closely associated to them. A number of attributes have been proposed as indirect selection criteria for genetic improvement of yields in plant breeding programs (Rebettzke et al, 2002). Heritability represents the relative importance of genetic and environment factors in the expression of phenotypic and genotypic differences among genotypes within a population (Kang et al, 1983; Dagar et al, 2002 cited by Ehib et al, 2015). Consequently, the knowledge of heritability related to important traits and the correlations among them are key issues to determine the best selection strategy (Hallauer and Miranda, 1988; Falconer, 1989). Genotypic coefficient of variation (GCV) is another measure of relative genetic variation of a trait within a population (Ram \& Hemaprabha, 1992). Traits exhibiting relatively high GCV estimates may respond favorably to selection. Chaudhary (2001) reported high GCV for single stalk weight and millable cane number per unit area. Genotype $\mathrm{x}$ environment interactions (GxE) are a serious concern in breeding programs as they affect selection decisions. When a rank of a genotype changes across environments, it requires evaluation of genotypes across environments to determine their real value (Kimbeng et al, 2002). Studies in various sugarcane breeding programs have reported significant GxE interactions for cane and sugar yields (Parfitt, 200; Kimbeng et al, 2002; Glaz \& Kang, 2008).

The objective of study was to evaluate the variability of thirty sugarcane genotypes through heritability, genetic gain and genetic variations of some yield and juice quality traits.

\section{Material and Methods}

\subsection{Site Characteristics}

The study was carried out on a Ferké 2 sugarcane field (R3-002) sprinkler irrigated with center pivot $\left(9^{\circ} 16^{\prime} \mathrm{N}\right.$, $5^{\circ} 22^{\prime} \mathrm{W}, 325 \mathrm{~m}$ a.s.l), in northern Ivory Coast. The prevailing climate is tropical dry with two seasons: one, starting from November to April, is dry and the other, from May to October, is wet. The dry season is marked by the Saharan trade wind, which blows over mid-November to late January. The rainfall pattern is unimodal and focussed on August and September which total amount of rainfall reaches almost half of the average annual rainfall $(1200 \mathrm{~mm})$ with an average daily temperature of $27^{\circ} \mathrm{C}$. Average maximum and minimum daily air temperatures reach 32.5 and $21^{\circ} \mathrm{C}$, respectively. To meet crop water requirements, the total amount of irrigation water required reaches $700 \mathrm{~mm} /$ year (Konan et al a-b, 2017; Péné et al, 2012). Both Ferké sugar mill plantations cover around 15500 ha with 10000 ha under irrigation and 3500 ha of rainfed village plantations, lie mainly on shallow or moderately deep soils built up on granites. Main soil units encountered are oxisols and temporally waterlogged soils in valley bottoms of Bandama and Lokpoho river basins with a sandy-clay texture.

\subsection{Cane Genotypes Used}

All 29 cane genotypes tested, of Reunion and Ivory Coast origin (RCI), derived from about 8,000 true seeds of 60 different families (or crosses) provided by eRcane Sugarcane Development Centre of Reunion Island in November 
2014 and sowed late December 2014. They were pre-selected within families over a period of three years involving three consecutive steps starting from one seedling to one stool of tillers and one line of $3 \mathrm{~m}$ long per genotype without replication. During this process, the genotypes used were pre-selected following ratings based on hybrid vigor, tillering ability, ratooning performance and tolerance to endemic diseases like smut, leaf scald, pokkah boeng and sugarcane streak mosaic (SCSM). Parents of genotypes investigated, as complex polyploids, were commercial varieties of different origins. The heterozygous and polyploidy nature of sugarcane has resulted in generations of greater genetic variability. Knowledge on the nature and magnitude of variability present in the genetic material is therefore of prime importance for breeders to conduct effective selection programs. Coefficients of variation along with heritability as well as genetic advance are very essential to improve any trait of sugarcane because this would help in knowing whether or not the desired objective could be achieved from the material to be investigated (Tadesse et al, 2014).

\subsection{Experimental Design}

The experiment was carried out from late March 2018 to mid-February 2020 in plant cane and first ratoon, following a randomized complete block design (RCBD) with 30 different genotypes, including the check variety $\mathrm{R} 579$, in 3 replicates. A plot comprised 2 dual rows of $5 \mathrm{~m}$ long with narrow and wide spacings of $0.50 \mathrm{~m}$ and 1.90 $\mathrm{m}$. Field managements in terms of sprinkler irrigation, fertilizer and herbicide applications were done according to usual practices in commercial plantations.

\subsection{Agronomic Traits Investigated}

Data was collected at harvest from both dual rows for millable stalk number/ha, cane yield, juice quality traits (sucrose, purity, and recoverable sucrose), fiber content, and damaged internodes by stem borer (Eldana saccharina $\mathrm{W})$.

At harvest, burned cane fresh production of both dual rows of each plot was weighed separately to determine crop yield. Moreover, 50 millable stalks were randomly chosen within every plot and split longitudinally with a machete in order to determine the percentage of bored or attacked internodes and cane (\%BIN, \%BC) by stem borer.

Thirty millable cane stalks were sampled per plot for sucrose analyses in the laboratory. Prior to sample grinding operations in the laboratory for sucrose analyses, each stalk was cut into 3 pieces of almost equal length, while separating them in basal, median and top parts. This allowed to randomly reconstitute 3 batches of 10 stalks for a better homogenization of the initial field sample by permutation of the pieces so that each reconstituted stalk was composed of parts from 3 different cane stalks. Eventually, only one batch of 10 reconstituted stalks over $30(1 / 3$ of initial sample) were ground for a series of sucrose analyses to determine the sucrose content $(\mathrm{Pol} \% \mathrm{C})$, fiber content (Fiber \%C), juice purity (Purity \%C) and recoverable sucrose $(\mathrm{SE} \% \mathrm{C})$. Equipment used comprised a Jefco cutter grinder, a hydraulic press (Pinette Emideceau), a digital refractometer BS-RFM742 and a digital polarimeter SH-M100. Hoarau (1970) reported on methods used in the determination of required technological parameters. The recoverable sucrose was calculated as follows (Hugot, 1999; Péné et al, 2016):

$\mathrm{SE} \% \mathrm{C}=[(0.84 \times \mathrm{Pol} \% \mathrm{C})(1.6-60 /$ Purity $)-(0.05 \times \mathrm{Fib} \% \mathrm{C})]$ with:

Purity $\% \mathrm{C}=($ Pol juice/Brix $) \times 100$ and Pol juice $=$ Pol factor $\times$ Pol read.

$\mathrm{Pol} \% \mathrm{C}=$ Factor $\mathrm{n} \times \mathrm{Pol}$ juice

Factor pol, depending on brix value (amount of soluble dry matter in juice measured with a refractometer), was provided by Schmidt table relative to a polarimeter for $26 \mathrm{~g}$ of glucose. The fiber content and factor $n$ were provided by a table, depending on the weight of fiber cake obtained after pressing $500 \mathrm{~g}$ of cane pulp resulting from the grinding operation of each sample of cane stalks.

\subsection{Phenotypic and Genotypic Coefficients of Variation, Heritability and Genetic Advance}

The phenotypic and genotypic variances for each trait were estimated from the RCBD analysis of variance (Table 1). The expected mean squares under the assumption of random effects model was computed from linear combinations of mean squares were determined as follows (Burton \& Davane, 1953 cited by Shitahum et al, 2018):

Genotypic variance $\left(\sigma_{\mathrm{g}}^{2}\right)=\left(\mathrm{MS}_{\mathrm{g}}-\mathrm{MS}_{\mathrm{e}}\right) / \mathrm{r}$

Environmental variance $\left(\sigma_{\mathrm{e}}^{2}\right)=\mathrm{MS}_{\mathrm{e}}$

Phenotypic variance $\left(\sigma_{\mathrm{p}}^{2}\right)=\sigma_{\mathrm{g}}^{2}+\sigma_{\mathrm{e}}^{2}$

Where MSg and MSe are mean sum of squares for genotypes and error in the analysis of variance, respectively, and $r$ the number of replicates. 
Genotypic and phenotypic coefficients of variation (GCV, PCV) were computed as follows (Singh \& Chaundary, 1977):

$\mathrm{GCV}=\sigma_{\mathrm{g}} \times 100 /$ grand mean

$\mathrm{PCV}=\sigma_{\mathrm{p}} \times 100 /$ grand mean

Broad sense heritability $\mathrm{h}^{2}=100 \times \sigma_{\mathrm{g}}^{2} / \sigma_{\mathrm{p}}^{2}$

Genetic advance (GA) and genetic advance as percent mean (GAM): $\mathrm{GA}=\mathrm{k} \mathrm{x} \mathrm{h}^{2} \times \sigma_{\mathrm{p}}$ and GAM $=100 \times \mathrm{GA} / \mathrm{X}$ With $\mathrm{k}$ : standard selection differential at $5 \%$ selection intensity $(\mathrm{k}=2.063)$ and $\mathrm{X}$ : grand mean of trait $\mathrm{X}$.

Phenotypic and genotypic correlation coefficients $r_{p}$ and $r_{g}$ between $A$ and $B$ traits are defined as:

$\mathrm{r}_{\mathrm{p}}=\operatorname{Cov}_{\mathrm{p}}(\mathrm{A}, \mathrm{B}) /\left(\sigma_{\mathrm{pA}} \times \sigma_{\mathrm{pB}}\right)$

$r_{\mathrm{g}}=\operatorname{Cov}_{\mathrm{g}}(\mathrm{A}, \mathrm{B}) /\left(\sigma_{\mathrm{gA}} \times \sigma_{\mathrm{gB}}\right)$

where similarly to the phenotypic variance equation, the phenotypic covariance $\operatorname{Cov}_{\mathrm{p}}$ is expressed as:

$\operatorname{Cov}_{\mathrm{p}}=\operatorname{Cov}_{\mathrm{g}}+\operatorname{Cov}_{\mathrm{e}}$

\subsection{Statistical Analyses}

The quantitative data recorded in this study was subjected to the analysis of variance using statistical procedures described by Gomez \& Gomez (1984), with the assistance of R software package version 3.5.1 (Table 1).

Table 1. Analysis of variance calculations in a RCBD involving GxY interactions

\begin{tabular}{lrrr}
\hline Source of variation & Degree of freedom (df) & Mean square (MS) & Expected mean square (EMS) \\
\hline Replication (R) & $\mathrm{y}(\mathrm{r}-1)$ & $\mathrm{MSr}$ & \\
Years (Y) & $\mathrm{y}-1$ & & \\
Genotypes (G) & $\mathrm{g}-1$ & $\mathrm{M} 1=\mathrm{MSg}$ & $\sigma_{\mathrm{e}}^{2}+\mathrm{r}_{\mathrm{gy}}^{2}+\mathrm{ry}_{\mathrm{g}}^{2}$ \\
G x Y & $(\mathrm{g}-1)(\mathrm{y}-1)$ & $\mathrm{M} 2=\mathrm{MSgy}$ & $\sigma_{\mathrm{e}}^{2}+\mathrm{r}_{\mathrm{gy}}^{2}+\mathrm{ry}_{\mathrm{g}}^{2}$ \\
Error (G x R) & $(\mathrm{r}-1)(\mathrm{gy}-1)$ & $\mathrm{M} 3=\mathrm{MSe}$ & \\
Total & $\mathrm{gyr}-1$ & & $\sigma_{\mathrm{e}}^{2}$ \\
\hline
\end{tabular}

$\mathrm{R}:$ number of replicates; $\mathrm{g}=$ number of genotypes; MSr mean square due to replicates; $\mathrm{MSg}=$ mean square due to genotypes; MSe mean square of error; $\sigma^{2} \mathrm{~g}, \sigma^{2} \mathrm{r}, \sigma^{2} \mathrm{y}$ and $\sigma^{2} \mathrm{e}$ stand for variances due to genotypes, replicates, years and error, respectively.

\section{Results and Discussion}

\subsection{Climatic Conditions Over Plant Cane and First Ratoon Crop}

The total amount of rainfall recorded in plant cane was similar to that in first ratoon, with 1311 and $1303 \mathrm{~mm}$, respectively. However, total rainfall during in the hottest period (from April to July) decreased by $51.4 \%$ in the first ratoon compared to that of plant cane, with 352.7 and $726.2 \mathrm{~mm}$ respectively. In contrast, the amount of rainfall recorded over the cloudy and per-humid period (from August to October) increased by $59 \%$, with 554.6 and $880.7 \mathrm{~mm}$ respectively in plant cane and first ratoon (Fig 1). Total crop water deficit over the dry season to be met with irrigation water reached 571 and $565 \mathrm{~mm}$, respectively, in plant cane and first ratoon. The average daily temperature over the entire crop cycle yields 27.8 and $26.8^{\circ} \mathrm{C}$, respectively. 


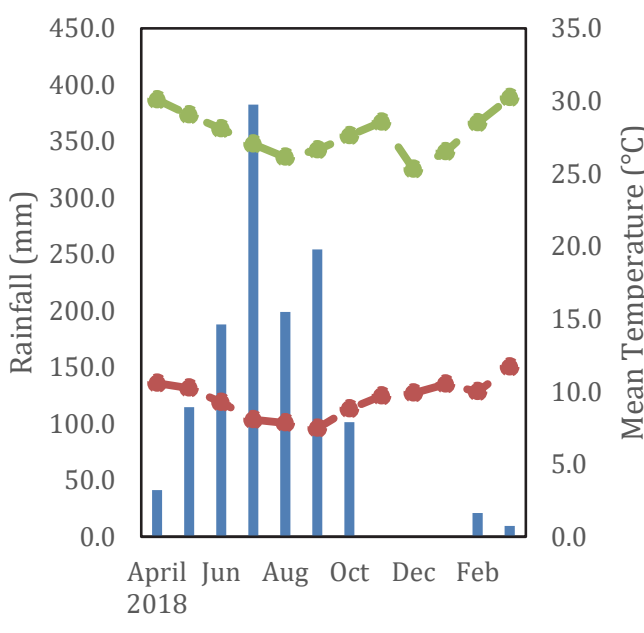

Months

Rainfall - ETo $-\mathrm{C}$ Temp

Fig 1a. Climate over plant cane.

Figure 1. Prevailing climate on experimental site over both crop cycles in Ferké 2 sugar estate, Ivory Coast

\subsection{Multivariate ANALYSES}

It came out from the principal component analysis (Figure 2) that most relevant traits in genotype clustering were related to juice quality (recoverable sucrose, sucrose content, purity, fiber content), and some yield components like stalk diameter and average stalk diameter. The dendrogram deduced from the hierarchical ascendant classification analysis (Figure 3) exhibits six different cluster genotypes, which average agronomic characteristics are displayed in Table 2 .

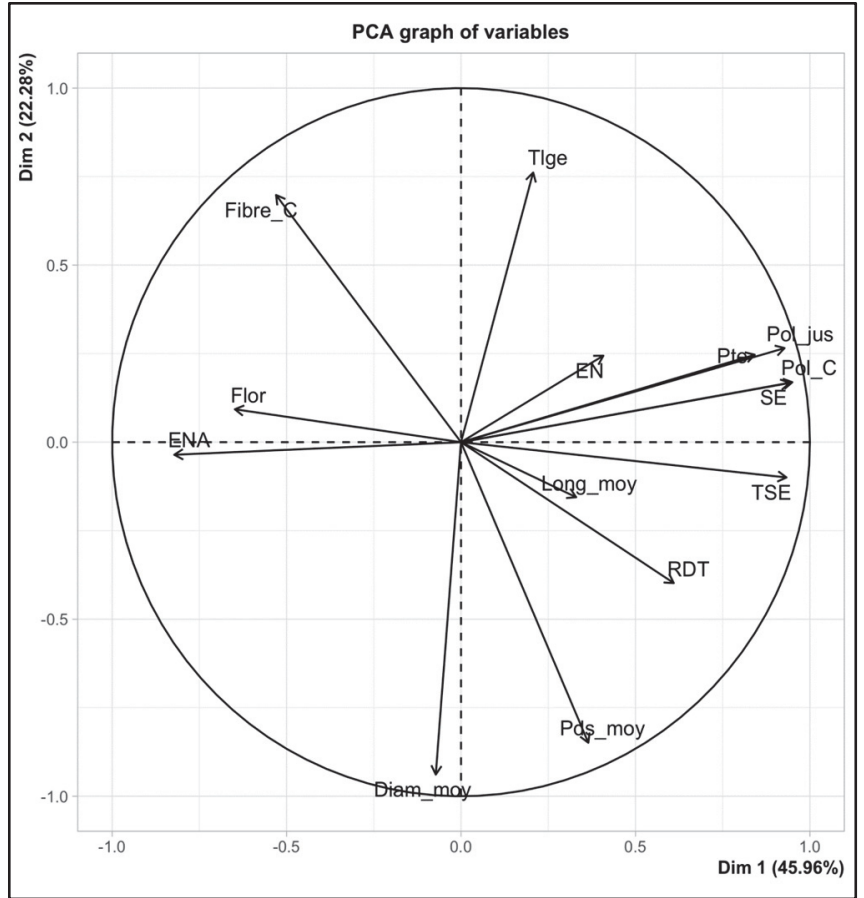

Figure 2a. Correlation circle of agronomic traits investigated in 1-2 factor plane.

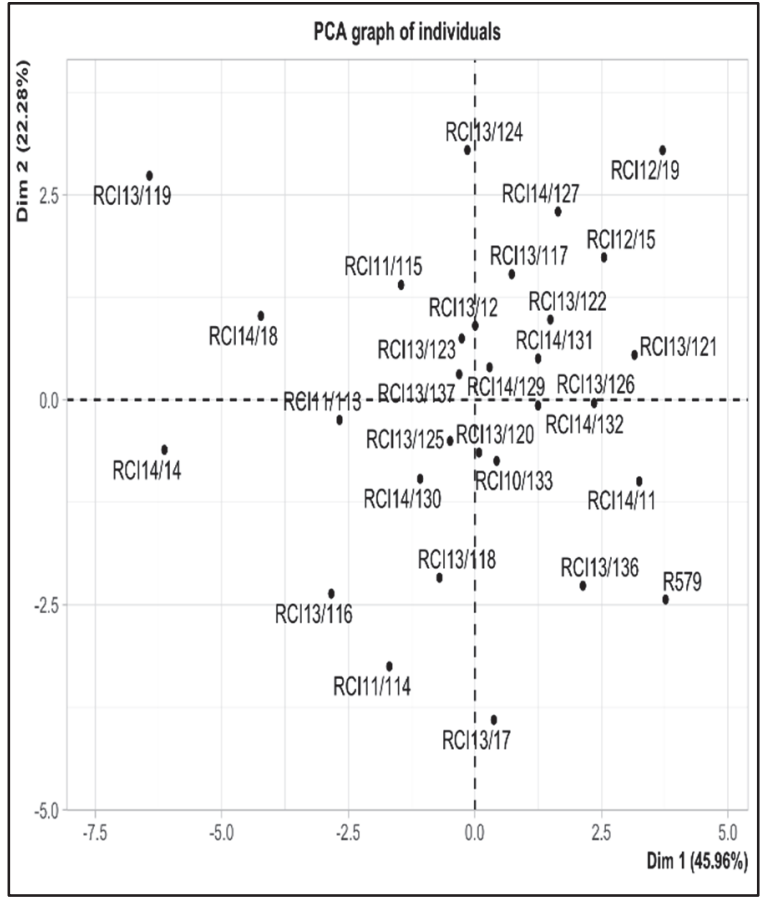

Figure $2 \mathrm{~b}$. Projection of sugarcane genotypes in 1-2 factor plane.

Figure 2. Results of Principal Component Analysis regarding aggregate data of both plant and first ratoon crops 


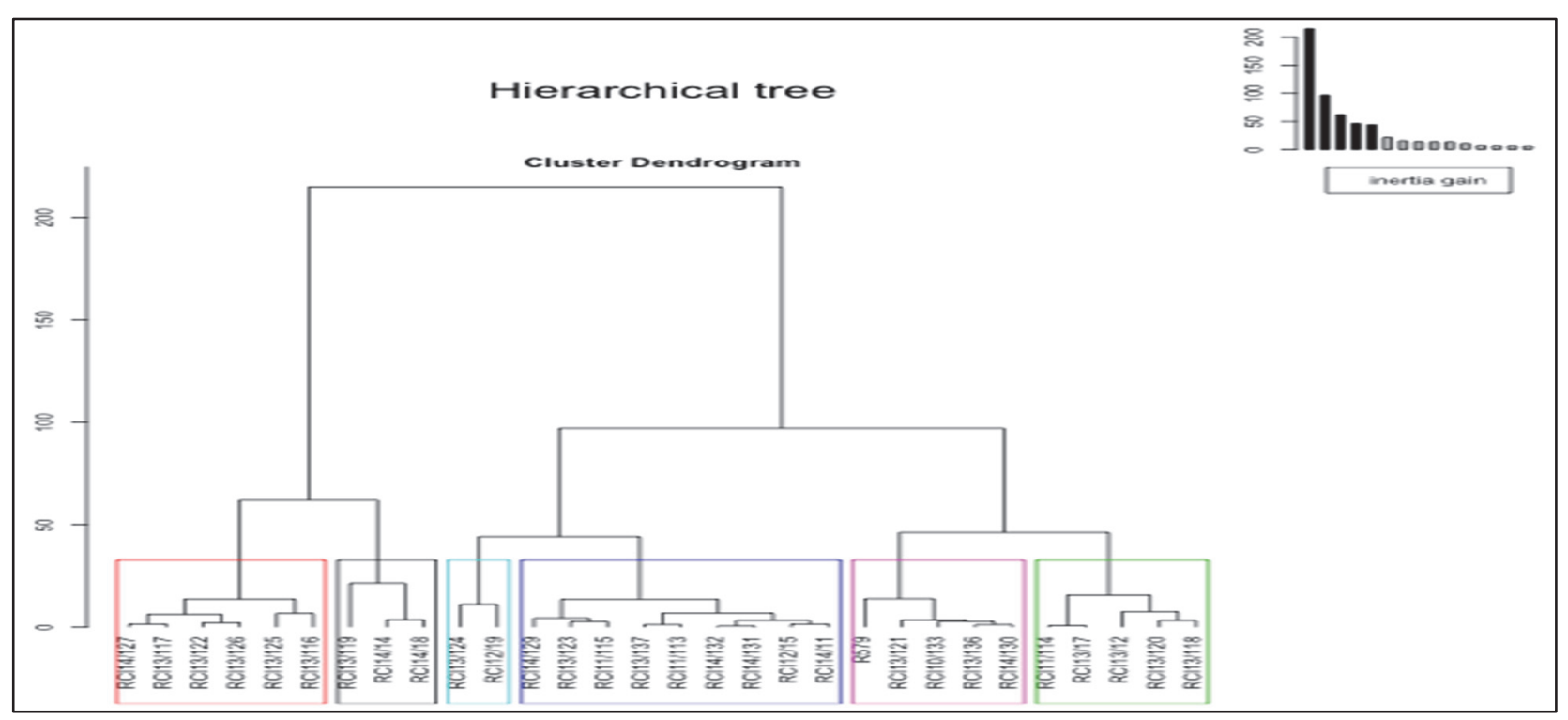

Figure 3. Dendrogram deduced from cluster analysis of all 30 cane genotypes tested in Ferké 2 sugar estate, Ivory Coast

Table 2. Mean values of clusters genotypes determined following different agronomic traits investigated in Ferké 2 sugar estate, Ivory Coast (aggregate of plant cane and first ratoon)

\begin{tabular}{lrrrrrr}
\hline Agronomic traits & $\begin{array}{r}\text { Cluster 1 } \\
(\mathrm{n}=3)\end{array}$ & $\begin{array}{r}\text { Cluster 2 } \\
(\mathrm{n}=5)\end{array}$ & $\begin{array}{r}\text { Cluster 3 } \\
(\mathrm{n}=6)\end{array}$ & $\begin{array}{r}\text { Cluster 4 } \\
(\mathrm{n}=9)\end{array}$ & $\begin{array}{r}\text { Cluster 5 } \\
(\mathrm{n}=2)\end{array}$ & $\begin{array}{r}\text { Cluster 6 } \\
(\mathrm{n}=5)\end{array}$ \\
\hline Pol juice (\%) & 11.8 & 16.1 & 14.0 & 14.9 & 16.1 & 15.5 \\
Purity (\%) & 77.1 & 83.8 & 80.1 & 82.2 & 81.9 & 83.4 \\
Sucrose (Pol\%C) & 9.3 & 12.9 & 11.4 & 12.0 & 12.8 & 12.7 \\
Fiber content (\%) & 15.6 & 14.3 & 13.4 & 14.1 & 14.8 & 13.3 \\
Cane Yield (t/ha) & 95.8 & 108.5 & 130.7 & 128.5 & 133.5 & 146.8 \\
Recov Sucrose (\%) & 5.7 & 8.9 & 7.5 & 8.1 & 8.6 & 8.7 \\
Sugar Yield (t/ha) & 5.5 & 9.7 & 9.8 & 10.4 & 11.6 & 12.8 \\
StalkNbx1000 & 143.9 & 145.1 & 132.2 & 157.6 & 182.8 & 148.2 \\
\%BIN & 27.7 & 11.9 & 16.7 & 15.4 & 8.5 & 13.9 \\
Avg Weight (kg) & 0.8 & 1.0 & 1.1 & 1.0 & 0.9 & 1.2 \\
Avg Diam (mm) & 2.3 & 2.4 & 2.4 & 2.4 & 2.5 & 2.5 \\
Avg Height (cm) & 21.6 & 21.8 & 23.4 & 21.6 & 19.6 & 22.7 \\
Nb Internode & 20.0 & 24.0 & 20.9 & 21.2 & 24.4 & 21.9 \\
Flowering rate (\%) & 25.3 & 3.6 & 12.4 & 8.3 & 2.2 & 6.2 \\
\hline C1: RCI13/119, RCI14/14, RCI14/18; C2: R579, RCI13/121, RCI0/133, RCI13/136, RCI14/130; C3 : RCI14/127, \\
RCI13/117, RCI13/122, RCI13/126, RCI13/125, RCI13/116; C4: RCI/14/129, RCI13/123, RCI11/115, \\
RCI13/137, RCI11/113, RCI14/132, RCI14/131, RCI12/15, RCI14/11; C5: RCI13/124, RCI12/19; C6: RCI11/14, \\
RCI13/17, RCI13/12, RCI13/120, RCI13/118
\end{tabular}

\subsection{Phenotypic Correlations Within Agronomic Traits}

All yield and juice quality traits were negatively correlated with stem borer infestations, except for fiber content (Table 2), in line of findings reported by different authors (Gravois et al, 1992, Tena et al, 2016, Dumont et al, 2019). Fiber content was negatively correlated with yields and juice quality traits like juice sucrose, purity, 
sucrose percent and recoverable sucrose with coefficients ranging from -0.29 to -0.42 . Higher and positive correlation coefficients were obtained between sugar yield and juice quality traits, with values ranging from 0.78 to 0.86 . A strong and positive correlation was also observed between yield traits $(\mathrm{r}=0.80)$ as well as juice quality traits, with coefficients ranging from 0.80 to 0.99 . Except for fiber content, juice quality and yield traits were negatively correlated to stem borer infestation rate $(\mathrm{r}=-0.40$ to -0.73$)$. The stalk fiber content and single stalk weight were, respectively, positively and negatively correlated to stem borer infestation rate $(\mathrm{r}=0.34,-0.68)$. Moreover, sugarcane flowering rate affected negatively all juice quality and yield traits $(\mathrm{r}=-0.33$ to -0.53$)$.

\subsection{Genotypic Correlations Within Agronomic Traits}

Similarly with phenotypic correlations, all yield and juice quality traits were genotypically correlated negatively with stem borer infestations, except for fiber content (Table 2), with values ranging from -0.42 to -0.81 . As expected, strong and positive correlations were observed not only between juice quality traits but also between yield traits, with coefficients ranging from 0.83 to 0.99 . Strong and positive correlations were also obtained between sugar yield and juice quality attributes like pol juice, purity, sucrose content and recoverable sucrose (r= 0.79 to 0.89 ). Similarly to phenotypic correlations previously discussed, juice quality and yield traits were negatively correlated to stem borer infestation rate $(r=-0.42$ to -0.81$)$. The stalk fiber content and single stalk weight were, respectively, positively and negatively influenced by stem borer infestation rate $(\mathrm{r}=0.36,-0.40)$. Moreover, sugarcane flowering rate affected negatively all juice quality and yield traits $(\mathrm{r}=-0.44$ to -0.62$)$.

\subsection{Performance of Cane Genotypes Tested}

Except for stalk number/ha, highly significant differences within genotypes were observed for all agronomic traits investigated (Table 3). Significant or highly significant differences within crop cycles were observed for all traits except for Pol juice, recoverable sucrose, single stalk weight and the average number of internodes per stalk. In contrast, genotype by crop cycle interactions were non-significant except for stem-borer infestation rate, average number of internodes per stalk and flowering rate. Based on sugar yields, four genotypes, namely RCI12/15, $\mathrm{RCI} 12 / 19, \mathrm{RCI} 13 / 121$ and RCI13/136 were equivalent to the check variety R579 which performed $15.6 \mathrm{t} / \mathrm{ha}$. Their sugar yields ranged from 12.8 to $13.8 \mathrm{t} / \mathrm{ha}$, while their cane yields from 134.0 to $144.8 \mathrm{t} / \mathrm{ha}$ compared with 161.3 $\mathrm{t} / \mathrm{ha}$ for the control variety. Although a relatively high level of stem-borer infestation rate recorded, with $15.6 \%$ on average (almost three times the tolerable threshold value of 5\%), reasonable values of sucrose percent obtained with the promising genotypes ranged from 12.7 to $13.9 \%$ over both crop cycles, compared with $13.6 \%$ for the check.

\subsection{Phenotypic, Genotypic and Environmental Variance}

Regardless the trait considered, phenotypic variances obtained were higher than the genotypic ones. This shows a greater influence of the environment on genetic variations in line of observations made by different authors (Tadesse et al, 2014; Ehib et al, 2015). Moreover, except for traits like stalk number/ha, average stalk weight, height and diameter, genotypic variances calculated were higher than environmental ones, suggesting significant variations among genotypes (Table 4). Greater environmental variance in millable stalk number/ha compared to the genotypic variance could be explained by no significant difference observed due to a very lower values of genotypic coefficient of variation and heritability obtained, with 7.3 and $29.5 \%$ respectively.

\subsection{Genotypic and Phenotypic Coefficients of Variation ( GCV, PCV)}

GCV is another measure of relative genetic variation of a trait in a population (Ram and hemaprabha, 1992). Traits exhibiting relatively high GCV estimates may respond favorably to selection (Ebid et al, 2015). Regardless the trait considered, the phenotypic coefficient of variation was higher than the genotypic one, suggesting that apparent variations were not only due to genetics but also due to environmental influences (Table 4). However, differences between PCV and GCV for most traits were small in line of observations made by Ram (2005), indicating high prospects for genetic progress through selection under conditions of this study. As stated by Shivasubramanian \& Menon (1973) cited by Tadesse et al (2014), PCV and GCV values are ranked as low, medium and high, with 0 to $10 \%, 11$ to $20 \%$ and $>20 \%$ respectively. Based on that statement, all PCV and GCV values determined which ranged from 5 to $94 \%$, on the one hand, and from 3.5 to $83.9 \%$, on the other hand, ranged from low to high. As reported by different authors (Tadesse et al, 2014; Singh et al, 1994, Péné \& Béhou, 2019a,b), high GCV and PCV indicated that selection might be effective on traits investigated and their expression be relevant to the genotypic potential.

\subsection{Heritability and Genetic Advance}

Higher heritability values (Table 4) ranging from 61 to $80.5 \%$ were observed in traits like sugar yield, sucrose content $(62.6 \%)$, recoverable sucrose $(60.6 \%)$, fiber content $(72 \%)$, stem-borer infestation rate $(80.5 \%)$, number 
of internodes/stalk (67.7\%), and flowering rate (79.6\%). In contrast, lower and moderate values of heritability were observed for Pol juice (59.8\%), Juice purity (50.5\%), cane yield (53\%), millable stalk number/ha (29.5\%), single stalk weight (36.7\%), single stalk height (45\%), and single stalk diameter (38.7\%). This distinction was made following heritability scale as stated by Robinson et al (1949) and cited by Tadesse et al, 2014. In line of the scale used by Teklu et al (2014), higher values of genetic advance (GAM) were observed for sugar yield (36.2\%), recoverable sucrose $(24.3 \%)$, and flowering rate $(154 \%)$, suggesting that a significant proportion of the total variance was heritable and selection of these traits would be effective. Similar values were reported by different authors in sugarcane on single stalk weight (Nair et al, 1980; Singh et al, 1994; Ebid et al, 2015). As indicated by Vidya et al (2002), knowledge of variability and heritability of characters is essential for identifying those relevant to genetic improvement through selection. Moreover, the effectiveness of selection depends not only on heritability but also on genetic advance (Butterfield and Nuss, 2002; Shba et al, 2009). Higher levels of genetic advance (GAM) observed for cane yield and stem borer infestations were the result of broad sense heritability and high GCV for these traits, in line of findings reported by Bakshi (2005). The results suggest the existence of considerable scope for sugarcane improvement based on some cane yield components like number of millable stalks/ha, single stalk diameter and single stalk weight. Heritability estimates, together with expected genetic gain, are more useful than heritability values alone in predicting the effects of selecting best genotypes. Chaudhary (2001) reported high heritability and genetic gain for single cane weight followed by number of millable cane in a study of 36 clones, indicating substantial scope for cane yield improvement. On the other hand, sucrose content recorded low heritability and genetic gain suggesting little scope for improvement in this character (Pandey, 1989). Patel et al (2008) also reported high heritability estimates for single cane weight, number of internodes, number of tillers, hand refractrometer brix, cane diameter and millable cane height, which were associated with moderate to high genetic advance (23-190\%). Findings indicated that these characters could be improved through selection.

Table 2. Phenotypic and genotypic correlation matrix of agronomic traits investigated regarding aggregate data of both plant and first ratoon crops (respectively below and above diagonal)

\begin{tabular}{|c|c|c|c|c|c|c|c|c|c|c|c|c|c|c|}
\hline Genotypes & PolJ\%. & Pty\% & $\mathrm{Pol} \%$ & Fiber $\%$ & $\begin{array}{l}\text { Cane } \\
\text { Yield }\end{array}$ & RSucr. & $\begin{array}{l}\text { Sug. } \\
\text { Yield }\end{array}$ & $\begin{array}{c}3 \\
10 \mathrm{xNb} \\
\text { Tillers }\end{array}$ & $\% \mathrm{BIN}$ & AvWeight & AvHeight & AvgDiam & NbIntern. & Flow.\% \\
\hline Pol juice & 1.00 & 0.92 & 0.99 & -0.37 & 0.45 & 0.99 & 0.85 & 0.46 & -0.81 & 0.11 & 0.21 & -0.35 & 0.40 & -0.60 \\
\hline Purity & 0.91 & 1.00 & 0.92 & -0.36 & 0.37 & 0.95 & 0.79 & 0.40 & -0.67 & 0.09 & 0.00 & -0.24 & 0.29 & -0.44 \\
\hline $\mathrm{Pol} \% \mathrm{C}$ & 0.99 & 0.91 & 1.00 & -0.47 & 0.51 & 0.99 & 0.89 & 0.36 & -0.80 & 0.21 & 0.19 & -0.24 & 0.36 & -0.62 \\
\hline Fiber\% & -0.31 & -0.29 & -0.41 & 1.00 & -0.72 & -0.48 & -0.67 & 0.58 & 0.36 & -0.82 & 0.02 & -0.75 & 0.13 & 0.46 \\
\hline CYield & 0.36 & 0.32 & 0.42 & -0.61 & 1.00 & 0.50 & 0.83 & -0.02 & -0.42 & 0.74 & 0.32 & 0.37 & -0.01 & -0.44 \\
\hline RSucrose & 0.99 & 0.94 & 0.99 & -0.42 & 0.41 & 1.00 & 0.89 & 0.34 & -0.78 & 0.20 & 0.14 & -0.21 & 0.34 & -0.59 \\
\hline SYield & 0.83 & 0.78 & 0.86 & -0.59 & 0.80 & 0.86 & 1.00 & 0.20 & -0.71 & 0.50 & 0.29 & 0.04 & 0.20 & -0.59 \\
\hline SNbx103 & 0.30 & 0.26 & 0.25 & 0.35 & 0.08 & 0.23 & 0.19 & 1.00 & -0.30 & -0.97 & -0.37 & -0.99 & 0.17 & -0.23 \\
\hline$\% \mathrm{BIN}$ & -0.72 & -0.58 & -0.73 & 0.34 & -0.40 & -0.70 & -0.66 & -0.18 & 1.00 & -0.40 & -0.61 & 0.09 & -0.58 & 0.68 \\
\hline AvWeight & 0.09 & 0.07 & 0.17 & -0.68 & 0.53 & 0.16 & 0.38 & -0.52 & -0.30 & 1.00 & 0.35 & 0.80 & 0.04 & -0.40 \\
\hline AvHeight & 0.18 & 0.04 & 0.18 & -0.01 & 0.32 & 0.14 & 0.29 & -0.16 & -0.48 & 0.39 & 1.00 & -0.06 & 0.56 & -0.18 \\
\hline AvDiam & -0.27 & -0.22 & -0.18 & -0.61 & 0.20 & -0.17 & -0.01 & -0.74 & 0.09 & 0.78 & -0.04 & 1.00 & -0.53 & 0.02 \\
\hline NbInternode & 0.35 & 0.23 & 0.32 & 0.11 & 0.01 & 0.29 & 0.19 & 0.17 & -0.50 & 0.14 & 0.54 & -0.33 & 1.00 & -0.49 \\
\hline Flowering & -0.50 & -0.33 & -0.53 & 0.42 & -0.36 & -0.49 & -0.49 & -0.17 & 0.62 & -0.35 & -0.14 & -0.44 & -0.46 & 1.00 \\
\hline
\end{tabular}


Table 3. Mean values of agronomic traits in plant cane and first ratoon (on aggregate) for different genotypes tested in Ferké, Ivory Coast (1rst stage of advanced screening)

\begin{tabular}{|c|c|c|c|c|c|c|c|c|c|c|c|c|c|c|c|}
\hline Genotypes & & PolJ\% & Pty $\%$ & $\mathrm{Pol} \%$ & Fiber\% & $\begin{array}{l}\text { Cane } \\
\text { Yield } \\
\end{array}$ & RSucr\% & $\begin{array}{l}\text { Sug. } \\
\text { Yield } \\
\end{array}$ & $\begin{array}{l}3 \\
10^{\mathrm{xNb}} \\
\text { Tillers } \\
\end{array}$ & BIN\% & $\begin{array}{l}\text { AvWeight } \\
(\mathrm{kg})\end{array}$ & $\begin{array}{l}\text { AvHeight } \\
\text { (m) }\end{array}$ & $\begin{array}{l}\text { AvgDiam } \\
(\mathrm{mm})\end{array}$ & NbIntern. & Flow.\% \\
\hline R579 & & $16.5 \mathrm{ab}$ & $85.7 \mathrm{ab}$ & $13.6 \mathrm{ab}$ & $12.7 \mathrm{hi}$ & $161.3 \mathrm{a}$ & $9.7 \mathrm{ab}$ & $15.6 \mathrm{a}$ & 136.7 & $13.7 \mathrm{de}$ & $1.3 \mathrm{ab}$ & $2.5 \mathrm{ab}$ & $23.5 \mathrm{ab}$ & $21.2 \mathrm{~cd}$ & $2.0 \mathrm{hi}$ \\
\hline RCI10/133 & & $15.0 \mathrm{ab}$ & $83.2 \mathrm{ab}$ & 12.1ab & $14.3 \mathrm{~cd}$ & $140.8 \mathrm{ab}$ & $8.2 \mathrm{ab}$ & $11.5 \mathrm{bc}$ & 150.7 & $21.0 \mathrm{bc}$ & $1.1 \mathrm{ab}$ & $2.5 \mathrm{ab}$ & $23.1 \mathrm{ab}$ & $22.0 \mathrm{~cd}$ & $9.7 \mathrm{fg}$ \\
\hline $\mathrm{RCI11/113}$ & & $12.4 \mathrm{ef}$ & 77.6de & $10.0 \mathrm{fg}$ & $14.2 \mathrm{~cd}$ & $132.1 \mathrm{ab}$ & $6.2 \mathrm{ef}$ & $8.2 \mathrm{fg}$ & 154.5 & $19.9 \mathrm{bc}$ & $1.0 \mathrm{ab}$ & $2.4 \mathrm{ab}$ & $21.8 \mathrm{ab}$ & $21.4 \mathrm{~cd}$ & $15.2 \mathrm{~cd}$ \\
\hline RCI11/114 & & $12.8 \mathrm{de}$ & $77.2 \mathrm{ef}$ & $10.5 \mathrm{ef}$ & 12.9gh & $137.6 \mathrm{ab}$ & 6.6de & $9.0 \mathrm{ef}$ & 122.3 & $20.3 \mathrm{bc}$ & $1.2 \mathrm{ab}$ & $2.5 \mathrm{ab}$ & $23.6 \mathrm{ab}$ & $21.7 \mathrm{~cd}$ & $10.7 \mathrm{ef}$ \\
\hline RCI11/115 & & $14.0 \mathrm{ab}$ & 79.9ab & $11.2 \mathrm{~cd}$ & $14.5 \mathrm{bc}$ & $122.4 \mathrm{bc}$ & $7.3 \mathrm{bc}$ & $9.0 \mathrm{ef}$ & 158.8 & $22.1 \mathrm{bc}$ & $0.9 \mathrm{bc}$ & $2.2 \mathrm{de}$ & $20.8 \mathrm{bc}$ & $21.7 \mathrm{~cd}$ & $0.0 \mathrm{i}$ \\
\hline $\mathrm{RCI12/15}$ & & $17.3 \mathrm{a}$ & $86.8 \mathrm{a}$ & 13.9ab & $14.1 \mathrm{~cd}$ & $134.0 \mathrm{ab}$ & $9.9 \mathrm{a}$ & 13.1ab & 154.8 & $9.5 \mathrm{hi}$ & $0.9 \mathrm{bc}$ & $2.3 \mathrm{bc}$ & $21.0 \mathrm{bc}$ & $20.6 \mathrm{de}$ & 12.ef0 \\
\hline RCI12/19 & & $17.0 \mathrm{ab}$ & $84.6 \mathrm{ab}$ & 13.6ab & $14.5 \mathrm{bc}$ & $144.8 \mathrm{ab}$ & $9.5 \mathrm{ab}$ & $13.8 \mathrm{ab}$ & 180.2 & $4.7 \mathrm{k}$ & $0.9 \mathrm{ab}$ & $2.6 \mathrm{ab}$ & $19.2 \mathrm{e}$ & $26.0 \mathrm{ab}$ & $3.3 \mathrm{hg}$ \\
\hline $\mathrm{RCI13/116}$ & & $12.3 \mathrm{fg}$ & 77.6de & $10.0 \mathrm{fg}$ & $13.8 \mathrm{de}$ & $116.2 \mathrm{bc}$ & $6.3 \mathrm{ef}$ & $7.3 \mathrm{gh}$ & 130.5 & $18.8 \mathrm{bc}$ & $1.2 \mathrm{ab}$ & $2.3 \mathrm{ab}$ & $24.2 \mathrm{ab}$ & $21.3 \mathrm{~cd}$ & $9.7 \mathrm{ef}$ \\
\hline $\mathrm{RCI13/117}$ & & $16.2 \mathrm{ab}$ & $83.4 \mathrm{ab}$ & 13.1ab & $14.2 \mathrm{~cd}$ & $107.4 \mathrm{~cd}$ & $9.0 \mathrm{ab}$ & $9.7 \mathrm{bc}$ & 148.7 & $13.4 \mathrm{ef}$ & $0.9 \mathrm{bc}$ & $2.2 \mathrm{~cd}$ & $21.4 \mathrm{~cd}$ & $22.6 \mathrm{~cd}$ & $3.8 \mathrm{gh}$ \\
\hline $\mathrm{RCI13} / 118$ & & 14.1ab & $81.1 \mathrm{ab}$ & $11.4 \mathrm{bc}$ & $13.4 \mathrm{fg}$ & $136.3 \mathrm{ab}$ & 7.6ab & $10.4 \mathrm{bc}$ & 135.7 & $17.5 \mathrm{bc}$ & $1.1 \mathrm{ab}$ & $2.1 \mathrm{ef}$ & $24.1 \mathrm{ab}$ & $18.7 \mathrm{~h}$ & $6.5 \mathrm{ef}$ \\
\hline $\mathrm{RCI13} / 119$ & & $11.8 \mathrm{gh}$ & $78.0 \mathrm{~cd}$ & $9.2 \mathrm{hi}$ & $15.7 \mathrm{ab}$ & 97.1fg & $5.7 \mathrm{fg}$ & $5.5 \mathrm{ij}$ & 160.8 & $37.3 \mathrm{a}$ & $0.7 \mathrm{c}$ & $2.1 \mathrm{f}$ & $20.3 \mathrm{~cd}$ & $20.6 \mathrm{de}$ & $32.0 \mathrm{a}$ \\
\hline $\mathrm{RCI13/12}$ & & $15.5 \mathrm{abc}$ & $82.9 \mathrm{ab}$ & $12.2 \mathrm{ab}$ & $15.3 \mathrm{ab}$ & $131.5 \mathrm{ab}$ & $8.2 \mathrm{ab}$ & $10.7 \mathrm{bc}$ & 141.7 & $12.8 \mathrm{fg}$ & $1.0 \mathrm{ab}$ & $2.8 \mathrm{a}$ & $20.9 \mathrm{bc}$ & $21.9 \mathrm{~cd}$ & $27.4 \mathrm{ab}$ \\
\hline $\mathrm{RCI13} / 120$ & & 15.0abc & $82.7 \mathrm{ab}$ & $12.3 \mathrm{ab}$ & $12.9 \mathrm{gh}$ & $125.9 \mathrm{bc}$ & 8.4ab & $10.6 \mathrm{bc}$ & 139.5 & $13.7 \mathrm{de}$ & $0.9 \mathrm{ab}$ & $2.3 \mathrm{bc}$ & $22.7 \mathrm{ab}$ & $19.2 \mathrm{fg}$ & $13.8 \mathrm{de}$ \\
\hline $\mathrm{RCI13} / 121$ & & $16.1 \mathrm{abc}$ & $84.8 \mathrm{ab}$ & 13.1ab & 13.6ef & 144.6ab & $9.2 \mathrm{ab}$ & $13.3 \mathrm{ab}$ & 149.7 & $10.5 \mathrm{hi}$ & $1.0 \mathrm{ab}$ & $2.8 \mathrm{a}$ & $20.6 \mathrm{bc}$ & $24.7 \mathrm{bc}$ & $0.0 \mathrm{i}$ \\
\hline RCI13/122 & & $16.9 \mathrm{ab}$ & 84.4ab & 13.4ab & 14.9ab & $115.5 \mathrm{bc}$ & $9.3 \mathrm{ab}$ & $10.8 \mathrm{bc}$ & 142.3 & $16.2 \mathrm{~cd}$ & $1.1 \mathrm{ab}$ & $2.5 \mathrm{ab}$ & $21.5 \mathrm{ab}$ & $23.4 \mathrm{~cd}$ & $4.3 \mathrm{gh}$ \\
\hline $\mathrm{RCI13} / 123$ & & $14.5 \mathrm{abc}$ & $83.8 \mathrm{ab}$ & $11.7 \mathrm{ab}$ & $14.1 \mathrm{~cd}$ & $118.9 \mathrm{bc}$ & $8.0 \mathrm{ab}$ & $9.6 \mathrm{~cd}$ & 163.3 & $15.3 \mathrm{~cd}$ & $1 \mathrm{ab}$ & $2.2 \mathrm{~cd}$ & $22.1 \mathrm{ab}$ & $21.1 \mathrm{~cd}$ & $8.2 \mathrm{ef}$ \\
\hline RCI13/124 & & $15.1 \mathrm{abc}$ & $79.2 \mathrm{bc}$ & $12.0 \mathrm{ab}$ & 15.1ab & $122.1 \mathrm{bc}$ & $7.7 \mathrm{ab}$ & $9.4 \mathrm{de}$ & 185.3 & $12.4 \mathrm{fg}$ & $0.9 \mathrm{bc}$ & $2.4 \mathrm{ab}$ & $20.0 \mathrm{de}$ & $22.9 \mathrm{~cd}$ & $1.0 \mathrm{hi}$ \\
\hline $\mathrm{RCI13} / 125$ & & $14.0 \mathrm{bc}$ & $79.2 \mathrm{bc}$ & $11.1 \mathrm{~cd}$ & $14.7 \mathrm{bc}$ & $102.9 \mathrm{de}$ & $7.1 \mathrm{~cd}$ & $7.4 \mathrm{fg}$ & 135.0 & $8.9 \mathrm{ij}$ & $1.2 \mathrm{ab}$ & $2.7 \mathrm{ab}$ & $22.5 \mathrm{ab}$ & $27.2 \mathrm{a}$ & $1.5 \mathrm{hi}$ \\
\hline RCI13/126 & & $16.3 \mathrm{ab}$ & $85.1 \mathrm{ab}$ & 13.3ab & 13.8de & $114.4 \mathrm{bc}$ & $9.3 \mathrm{ab}$ & $10.7 \mathrm{bc}$ & 145.0 & $5.8 \mathrm{jk}$ & $1.1 \mathrm{ab}$ & $2.4 \mathrm{ab}$ & $22.8 \mathrm{ab}$ & $24.2 \mathrm{bc}$ & $0.8 \mathrm{i}$ \\
\hline $\mathrm{RCI13/136}$ & & 15.4abc & $83.6 \mathrm{ab}$ & $12.7 \mathrm{ab}$ & $12.7 \mathrm{hi}$ & $146.9 \mathrm{ab}$ & $8.8 \mathrm{ab}$ & $12.8 \mathrm{ab}$ & 152.7 & $12.3 \mathrm{fg}$ & $1.3 \mathrm{a}$ & $2.4 \mathrm{ab}$ & $23.9 \mathrm{ab}$ & $21.0 \mathrm{~cd}$ & $7.7 \mathrm{ef}$ \\
\hline RCI13/137 & & $14.5 \mathrm{abc}$ & $82.6 \mathrm{ab}$ & 11.6ab & $14.3 \mathrm{~cd}$ & $128.7 \mathrm{ab}$ & $7.8 \mathrm{ab}$ & $10.1 \mathrm{bc}$ & 157.7 & $16.0 \mathrm{~cd}$ & $1.1 \mathrm{ab}$ & $2.4 \mathrm{ab}$ & $22.1 \mathrm{ab}$ & $22.2 \mathrm{~cd}$ & $15.9 \mathrm{~cd}$ \\
\hline $\mathrm{RCI13/17}$ & & $14.3 \mathrm{abc}$ & $79.3 \mathrm{bc}$ & $11.9 \mathrm{ab}$ & $12.4 \mathrm{i}$ & $136.9 \mathrm{ab}$ & $7.8 \mathrm{~b}$ & $10.5 \mathrm{bc}$ & 123.5 & $17.1 \mathrm{bc}$ & $1.3 \mathrm{a}$ & $2.5 \mathrm{ab}$ & $25.0 \mathrm{a}$ & $22.7 \mathrm{~cd}$ & $6.3 \mathrm{ef}$ \\
\hline RCI14/11 & & 17.1ab & $85.4 \mathrm{ab}$ & $14.1 \mathrm{a}$ & 12.9gh & $137.7 \mathrm{ab}$ & $10.0 \mathrm{a}$ & $13.7 \mathrm{ab}$ & 146.7 & $11.5 \mathrm{gh}$ & $1.2 \mathrm{ab}$ & $2.6 \mathrm{ab}$ & $22.9 \mathrm{ab}$ & $21.6 \mathrm{~cd}$ & $10.8 \mathrm{ef}$ \\
\hline RCI14/127 & & 17.1ab & $86.8 \mathrm{a}$ & 13.9ab & 13.8de & $102.4 \mathrm{de}$ & $9.9 \mathrm{a}$ & $10.2 \mathrm{bc}$ & 154.7 & $15.1 \mathrm{~cd}$ & $0.9 \mathrm{bc}$ & $2.3 \mathrm{~cd}$ & $20.6 \mathrm{bc}$ & $22.5 \mathrm{~cd}$ & $7.7 \mathrm{ef}$ \\
\hline $\mathrm{RCI14} / 129$ & & $15.2 \mathrm{abc}$ & $80.1 \mathrm{ab}$ & $12.2 \mathrm{ab}$ & $14.4 \mathrm{~cd}$ & 133.0ab & $8.0 \mathrm{ab}$ & $10.6 \mathrm{bc}$ & 165.2 & 14.1de & $1.0 \mathrm{ab}$ & $2.5 \mathrm{ab}$ & $22.0 \mathrm{ab}$ & $20.2 \mathrm{ef}$ & 3.0gh \\
\hline RCI14/130 & & $13.1 \mathrm{~cd}$ & 77.6de & 10.6de & $13.9 \mathrm{~cd}$ & $149.5 \mathrm{ab}$ & $6.6 \mathrm{de}$ & $10.0 \mathrm{bc}$ & 152.7 & $14.6 \mathrm{~cd}$ & $1.1 \mathrm{ab}$ & $2.5 \mathrm{ab}$ & $22.1 \mathrm{ab}$ & $21.1 \mathrm{~cd}$ & 7.1ef \\
\hline RCI14/131 & & $15.6 \mathrm{abc}$ & $82.2 \mathrm{ab}$ & $12.5 \mathrm{ab}$ & $14.0 \mathrm{~cd}$ & $131.2 \mathrm{ab}$ & $8.5 \mathrm{ab}$ & $11.1 \mathrm{bc}$ & 152.5 & $12.7 \mathrm{fg}$ & $1.1 \mathrm{ab}$ & $2.6 \mathrm{ab}$ & $20.8 \mathrm{bc}$ & $22.4 \mathrm{~cd}$ & $4.8 \mathrm{fg}$ \\
\hline RCI14/132 & & $15.6 \mathrm{abc}$ & $84.7 \mathrm{ab}$ & $12.8 \mathrm{ab}$ & $13.5 \mathrm{ef}$ & $128.0 \mathrm{ab}$ & $8.9 \mathrm{ab}$ & $11.4 \mathrm{bc}$ & 154.2 & 14.1de & $1.1 \mathrm{ab}$ & $2.4 \mathrm{ab}$ & $22.1 \mathrm{ab}$ & $20.0 \mathrm{ef}$ & 7.6ef \\
\hline RCI14/14 & & $11.3 \mathrm{~h}$ & $73.5 \mathrm{f}$ & $9.0 \mathrm{i}$ & 15.0ab & $90.8 \mathrm{~g}$ & $5.2 \mathrm{~g}$ & $4.8 \mathrm{j}$ & 130.8 & $24.2 \mathrm{~b}$ & $0.9 \mathrm{ab}$ & $2.5 \mathrm{ab}$ & $22.9 \mathrm{ab}$ & $18.9 \mathrm{gh}$ & $22.8 \mathrm{bc}$ \\
\hline RCI14/18 & & $12.5 \mathrm{ef}$ & 78.9ab & $9.7 \mathrm{gh}$ & $16.0 \mathrm{a}$ & $99.5 \mathrm{ef}$ & $6.1 \mathrm{ef}$ & $6.2 \mathrm{hi}$ & 140.0 & $21.6 \mathrm{bc}$ & $0.9 \mathrm{bc}$ & $2.5 \mathrm{ab}$ & $21.7 \mathrm{ab}$ & $20.6 \mathrm{de}$ & $21.0 \mathrm{bc}$ \\
\hline Mean & & 14.8 & 81.8 & 12.0 & 14.0 & 126.3 & 8.0 & 10.2 & 148.9 & 15.6 & 1.0 & 2.4 & 22.1 & 21.8 & 9.2 \\
\hline SD & & 2.2 & 4.9 & 1.9 & 1.7 & 23.7 & 1.7 & 3.1 & 38.5 & 7.6 & 0.2 & 0.3 & 2.4 & 2.7 & 11.5 \\
\hline CV(\%) & & 15.1 & 6.0 & 15.7 & 11.9 & 18.8 & 21.6 & 30.6 & 26.0 & 48.6 & 23.6 & 11.2 & 11.0 & 12.0 & 125.0 \\
\hline Replications & & $\mathrm{Ns}$ & Ns & Ns & Ns & $* *$ & $\mathrm{Ns}$ & Ns & $* * *$ & $* *$ & $*$ & Ns & Ns & $* *$ & Ns \\
\hline Genotypes & & $* * *$ & $* * *$ & $* * *$ & $* * *$ & $* * *$ & $* * *$ & $* * *$ & Ns & $* * *$ & $* * *$ & $* * *$ & $* * *$ & $* * *$ & $* * *$ \\
\hline Crop cycles & & Ns & $* * *$ & $* * *$ & $* * *$ & $*$ & Ns & $* *$ & $* * *$ & $* * *$ & $\mathrm{Ns}$ & $* * *$ & $* * *$ & Ns & $* * *$ \\
\hline Genotypes & $\mathrm{x}$ & $\mathrm{Ns}$ & $\mathrm{Ns}$ & Ns & $\mathrm{Ns}$ & Ns & Ns & $\mathrm{Ns}$ & Ns & $* * *$ & $\mathrm{Ns}$ & $\mathrm{Ns}$ & $\mathrm{Ns}$ & $* * *$ & $* * *$ \\
\hline
\end{tabular}

$\overline{\mathrm{SNb}}$ : millable stalk number/ha; BIN: bored internode; AvWeight: average stalk weight; AvHeight: average stalk height; Ns: non-significant.

$*, * * * * *$ : significant at 5,1 and $0.1 \%$ levels of probability. 
Table 4. Variability and heritability among sugarcane genotypes tested as plant crop and first ratoon (aggregate data) in Ferké, Ivory Coast

\begin{tabular}{|c|c|c|c|c|c|c|c|c|c|}
\hline \multirow[t]{2}{*}{ Variability } & \multirow[t]{2}{*}{ Mean } & \multicolumn{3}{|c|}{ Variance } & \multicolumn{2}{|c|}{$\begin{array}{c}\text { Coef. of variation } \\
(\%)\end{array}$} & \multirow[t]{2}{*}{$\mathrm{h}^{2}(\%)$} & \multirow[t]{2}{*}{ GA } & \multirow[t]{2}{*}{ GAM (\%) } \\
\hline & & $\sigma_{\mathrm{p}}^{2}$ & $\sigma_{\mathrm{e}}^{2}$ & $\sigma_{g}^{2}$ & PCV & GCV & & & \\
\hline Juice sucrose $\%$ & 14.8 & 4.0 & 1.6 & 2.4 & 13.5 & 10.4 & 59.8 & 2.5 & 16.7 \\
\hline Purity $\%$ & 81.8 & 16.7 & 8.2 & 8.4 & 5.0 & 3.5 & 50.5 & 4.2 & 5.2 \\
\hline Sucrose $\%$ & 12.0 & 2.8 & 1.0 & 1.7 & 13.9 & 11.0 & 62.6 & 2.1 & 18.0 \\
\hline Fiber content $\%$ & 14.0 & 1.0 & 0.3 & 0.7 & 7.1 & 6.0 & 72.1 & 1.5 & 10.6 \\
\hline Cane yield (t/ha) & 123.3 & 426.6 & 200.6 & 226.0 & 16.7 & 12.2 & 53.0 & 22.6 & 18.3 \\
\hline Recov. sucrose $\%$ & 8.0 & 2.4 & 1.0 & 1.5 & 19.4 & 15.1 & 60.6 & 1.9 & 24.3 \\
\hline Sugar yield (t/ha) & 10.2 & 8.1 & 3.0 & 5.1 & 27.8 & 22.1 & 63.0 & 3.7 & 36.2 \\
\hline Stalk number/ha & 148.9 & 396.0 & 279.0 & 117.0 & 13.4 & 7.3 & 29.5 & 12.1 & 8.1 \\
\hline Bored internode & 15.6 & 43.8 & 8.5 & 35.3 & 42.6 & 38.2 & 80.5 & 11.0 & 10.7 \\
\hline Avg weight (kg) & 1.0 & 0.0 & 0.0 & 0.0 & 19.3 & 11.7 & 36.7 & 0.1 & 14.6 \\
\hline Avg height (m) & 2.4 & 0.05 & 0.0 & 0.0 & 9.0 & 6.0 & 45.1 & 0.2 & 8.4 \\
\hline Avg diameter (mm) & 22.1 & 3.3 & 2.0 & 1.3 & 8.2 & 5.1 & 38.7 & 1.4 & 6.5 \\
\hline $\mathrm{Nb}$ Internodes & 21.8 & 4.6 & 1.5 & 3.1 & 9.8 & 8.0 & 67.7 & 3.0 & 13.7 \\
\hline Flowering rate $\%$ & 9.2 & 75.1 & 15.3 & 59.8 & 94.0 & 83.9 & 79.6 & 14.2 & 154.4 \\
\hline
\end{tabular}

PCV: phenotypic CV (\%); GCV: genotypic CV (\%); $\mathrm{h}^{2}$ : broad sense heritability; GA: genetic advance; GAM: genetic advance as percent of mean (\%)

\section{Conclusions}

Based on sugar yields, four promising genotypes namely RCI12/15, RCI12/19, RCI13/121 and RCI13/136 were equivalent to the check variety R579 which performed $15.6 \mathrm{t} / \mathrm{ha}$. They are due to undergo the advanced selection stage during the 2020-21 cropping season for three more years for determining the first new sugarcane varieties of RCI origin to be tested commercially in Ferké sugar estates. Their yield performances ranged from 12.8 to 13.8 $\mathrm{t}$ sugar /ha, i.e. from 134.0 to $144.8 \mathrm{t}$ cane/ha compared with $161.3 \mathrm{t} / \mathrm{ha}$ for the control variety. Although a relatively high level of stem-borer infestation rate recorded with $15.6 \%$ on average (almost three times the tolerable threshold value of $5 \%$ ), reasonable values of sucrose percent obtained with the promising genotypes, ranged from 12.7 to $13.9 \%$ over both crop cycles, compared with $13.6 \%$ for the check. Higher heritability values ranging from 61 to $80.5 \%$ were observed in traits like sugar yield, sucrose content $(62.6 \%)$, recoverable sucrose $(60.6 \%)$, fiber content (72\%), stem-borer infestation rate $(80.5 \%)$, number of internodes/stalk (67.7\%), and flowering rate $(79.6 \%)$. In contrast, lower and moderate values of heritability were observed for Pol juice (59.8\%), Juice purity (50.5\%), cane yield (53\%), millable stalk number/ha (29.5\%), single stalk weight (36.7\%), single stalk height (45\%), and single stalk diameter (38.7\%).

\section{References}

Ali, A., Khan, S. A., Farid, A., Khan, A., Khan, S M., \& Ali, N. (2017). Assessment of sugarcane genotypes for cane yield. Sarhad J Agric., 33(4), 668-73.

Chaudhary, R. R. (2001). Genetic variability and heritability in sugarcane. Nepal Agric. Res. J., 4, 56-9.

Dagar, P., Pahuja, S. K., Kaian, S. P., \& Singh. (2002). Evaluation of phenotypic variability in sugarcane using principal factor analysis. Ind. J. Sugarc. Technol., 17, 95-100.

Dahlquist, E. (2013). Biomass as Energy source: Resources, Systems and Applications, CRC Press, Taylor \& Francis, London.

Dumont, T., Thong-Chane, A., Barau, L., Siegmund, B., \& Hoarau, J. Y. (2019). Genetic variabilities and genetic gains for yield components in regional sugarcane breeding program on Reunion Island. Sugar Tech. http://doi.org/10.1007/s12355-019-00718-9

Ebid, M. H. M., Khalil, H. A., Abd-ElAal, A. M., \& Fergany, M. A. (2015). Heritability and genotypic and phenotypic correlations among sugarcane yield and some agronomic traits. Egypt L Plant Breed, 19(1), 15971.

Falconer, D. S. (1989). Introduction to quantitative genetics (3rd ed.). Longman, UK, p. 430.

FAO. (2013). FAO STAT. FAO statistical databases. Retrieved from http://faostat3.fao.org/ (Last accessed Dec. 18, 
2015).

FAO. (2014a). FAO STAT, FAO statistical databases. Retrieved from http://faostat3.fao.org/ (Last accessed June 07, 2016).

FAO. (2014b). Global sugarcane production statistics. Retrieved from http//faostat.fao.org/site/567/desktopDefault. Aspx?PageID=567\#

Glaz, B., \& Kang, M. S. (2008). Location contributions determined via GGE biplot analysis of multi-environment sugarcane genotype-performance trials. Crop Sci., 48, 941-50.

Goldemberg, J. (2008). The Brazilian biofuels industry. Biotechnol. for Biof., 1(1), 1.

Gravois KA \& Milligan SB. (1992). Genetic relationship between fiber and sugarcane yield components. Crop Sci., 32(1), 62-7.

Hallauer, A. R., \& Miranda, J. B. (1988). Quantitative genetics in maize breeding. Iowa State Univ. press, Ames, Iowa, p. 468.

Jackson, P. A. (2005). Breeding for improved sugar content in sugarcane. Field Crops Res., 92(2-3), $277-90$.

Kang, M. S., Miller, J. D., \& Tai, P. Y. P. (1983). Genotypic and phenotypic path analyses and heritability in sugarcane. Crop Sci., 23, 643-47.

Khan, I. A., Dahot, M. U., Seema, N., Yasmin, S., Bibi, S., Raza, S., \& Khatri, A. (2009. Genetic variability in sugarcane plantlets developed through in vitro mutagenesis Pakist. J. Biothechnol, 41(1), 153-66.

Kimbeng, C. A., Rattey, A. R., \& Hetherington, M. (2002). Interpretation and implications of GxE interactions in advanced stage sugarcane selection trials in central Queensland. Aust. J. Agric. Res., 53(9), 1035-45.

Moore, P. H., \& Botha, F. C. (2013). Flowering Sugarcane: Physiology, Biochemistry and functional Biology. John Wiley \& Sons, Inc, Chichester, UK.

Pandey, R. A. (1989). Variability study in the hybrid progenies of sugarcane (Saccharum complex). Bharatiya Sugar (Oct), 49-51.

Patel MM, Patel HS, Patel AD, Patel MP. (2008). Correlation and path analysis in sugarcane. Ind. Sugar, 31, 91114.

Péné, C. B., \& Béhou, Y. M. (2019b). Evaluation of sugarcane gonotypes under irrigation based on genetic variations and heritability for agronomic traits at early selection stage in Ferké, Ivory Coast. Am. J. Biosci. Bioeng. 7(6), 82-92.

Péné, C., B., \& Béhou, Y. M. (2019a). Screening of fifteen sugarcane genotypes under irrigation based on genetic variations and heritability for agro-morphological traits at early selection stage in Ferké, Ivory Coast. Am. J. Biom. Sci. Res., 4(5), 362-75.

Ram, B., \& Hemaprabha. (1992). Genetic variability in interspecific progenies in sugarcane (Saccharum spp.). Ind. J. Genet., 52(2), 192-98.

Ram, B. (2005). Estimation of genetic parameters in different environments and their implications in sugarcane breeding. In. J. Genet., 52(2), 192-98.

Rebettzke, G. J., Condon, A. G., Richards, R. A., \& Farquhar, G. D. (2002). Selection of carbon isotope discrimination increases aerial biomass and grain yield of rainfed bread wheat. Crop Sci., 42(3), 739-45.

Tadesse, F., Negi, T., Getaneh, A., Dilnesaw, Z., Ayele, N., \& Teferi, Y. (2014). Genetic variability and heritability of ten exotic sugarcane genotypes at Wonji sugar estate of Ethiopia. Global Adv. Res. J. Phys. Appl. Sci., 3(4).

Teklu, D. H., Kebede, S. A., \& Gebremichael, D. E. (2014). Assessment of genetic variability, genetic advance, correlation and path analysis for morphological traits in sesame genotypes. Asian J. Agric. Res., 8(4), 181194.

Tena, E., Ayana, A., \& Mekbib, F. (2016). Heritability and correlation among sugarcane yields and some agronomic and sugar quality traits in Ethiopia. Am. J. Pant Sci., 7(10), 1453-77.

Waclawovsky, A. J., Sato, P. M., Lembke, C. G., Moore, P. H., \& Souza, G. M. (2010). Sugarcane for bioenergy production: An assessment of yield and regulation of sucrose content. Plant Biotechnol. J., 8(3), 263-76.

Wei, X., Jackson, P., Cox, M., \& Stringer, J. (2006). Maximizing economic benefits to the whole sugarcane industry from BSES-CSIRO sugarcane improvement program. In: Proc. Aust. Soc. Sugarcane Technol. Vol 2006. PK editorial services, Brisbane, p. 181. 
Yang, X., Kandel, R., Song, J., You, Q., \& Wang, J. (2018). Sugarcane genome sequencing and genetic mapping. In: Achieving sustainable cultivation of sugarcane. Vol. 2: Breeding, pests and diseases. Ph Rot teds, Univ. Florida, USA.

\section{Copyrights}

Copyright for this article is retained by the author(s), with first publication rights granted to the journal.

This is an open-access article distributed under the terms and conditions of the Creative Commons Attribution license (http://creativecommons.org/licenses/by/4.0/). 